\title{
TEKNOLOGI PENGELOLAAN AIR SIAP MINUM DI DESA JAGO KABUPATEN LOMBOK TENGAH
}

\section{READY-TO-DRINK WATER MANAGEMENT TECHNOLOGY IN JAGO VILLAGE, LOMBOK CENTRAL DISTRICT}

\author{
Nurul Ismillayli'), Laili Mardiana ${ }^{2)}$, Rina Kurniasih ${ }^{3)}$, Dhony Hermanto ${ }^{1)}$, Fahrurazi ${ }^{1)}$ \\ ${ }^{1)}$ Program Studi Kimia, Fakultas MIPA, Universitas Mataram \\ ${ }^{2)}$ Program Studi Fisika Fakultas MIPA, Universitas Mataram \\ ${ }^{3)}$ Program Studi Biologi Fakultas MIPA, Universitas Mataram \\ Email: nurulismillayli12@gmail.com
}

Diterima: 28 Agustus 2017. Disetujui 7 September 2017. Dipublikasikan: 30 September 2017

\begin{abstract}
Abstrak: Pemenuhan kebutuhan air bersih yang aman dan layak dikonsumsi belum dapat dirasakan oleh semua lapisan masyarakat Lombok Tengah akibat tingginya angka kemiskinan dan rendahnya tingkat pendidikan masyarakat. Selain itu dengan tingginya aktivitas sektor pertanian yang menggunakan pupuk dan pestisida, dimungkinkan bahan kimia dan hasil peruraianya akibat proses leaching terbawa aliran air kemudian meresap ke dalam tanah dan masuk ke dalam sumber air tak terlindungi. Hal ini diindikasikan dengan hasil pengukuran kadar nitrit dan ammonia di beberapa sungai yang mengaliri desa. Salah satu solusi yang akan diterapkan dalam kegiatan ini adalah penerapan teknologi tepat guna tentang proses pengelolaan air siap minum dengan membuat unit pengolahan air irigasi menjadi air siap minum dengan menggunakan metode filtrasi-adsorpsi (kombinasi oleh pasir silika, karbon aktif dan membran) dan penyinaran lampu UV untuk desinfikasi. Sosialisasi kepada kelompok - kelompok tani Desa Jago dilakukan sebagai sarana alih teknologi tentang pengolahan air siap minum dan sebagai upaya mengedukasi masyarakat mengenai perilaku hidup bersih dan sehat serta pemanfaatan air secara bijak dan efektif. Keberlanjutan program dilakukan melalui pengelolaan mandiri oleh P3A dengan dukungan dari masyarakat sekitar dan pengawasan dari Perangkat Desa Jago.
\end{abstract}

Kata kunci: air siap minum, filtrasi, adsorpsi, uv radiasi, Desa Jago.

Abstract. Fulfillment of clean and safe drinking water needs cannot be felt by all levels of society in Central Lombok. The high rate of poverty and low level of education has become one of the contributing factors. In addition, the high activity of the agricultural sector using fertilizers and pesticides resulted in the chemicals and their decomposition carried by the water flow then seeping into the soil and entering into unprotected water sources. This is indicated by the results of measurement of nitrite and ammonia levels in several rivers running through the village. One solution that has been implemented is the application of appropriate technology in the process of drinking water management. The filtrationadsorption method was applied for making irrigation water treatment unit into ready-to-drink water. The method uses a combination of silica sand, activated carbon and membrane and UV light irradiation for disinfection. Technology transfer on ready-to-drink water treatment and efforts to educate people about clean and healthy living behavior, and wise and effective water utilization is done by socialization in the Jago village. The sustainability of the program is done through self-management by P3A with support from surrounding communities.

Keywords: drinking water, filtration, adsorption, uv radiation, Jago Village.

\section{PENDAHULUAN}

Penyediaan akses untuk air minum dan sanitasi yang layak merupakan kebutuhan dasar manusia yang menjadi perioritas utama dikarenakan berdampak pada kesehatan, perekonomian, dan lingkungan. Pada tahun 2013 diantara seluruh Provinsi di Indonesia, Nusa Tenggara Barat (NTB) merupakan salah satu provinsi yang kejadian diare berada di atas rata-rata nasional yaitu 4,1 persen. Pada tahun 2012 kejadian diare di NTB sebanyak 176,920 kasus yang tersebar di 10 Kabupaten/Kota [1] [2] termasuk Kabupaten Lombok Tengah yang memiliki luas wilayah $1.208,40 \mathrm{~km}^{2}$, atau $6 \%$ dari wilayah total NTB [3] sebanyak 28.756 kasus. 
Telah diidentifikasi bahwa kemiskinan merupakan faktor signifikan yang mempengaruhi kondisi sistem penyediaan air bersih yang aman dan layak terutama di daerah pedesaan [4]. Kabupaten Lombok Tengah dengan Kota Praya sebagai pusat pemerintahannya merupakan salah satu kabupaten dengan jumlah persentase penduduk miskin $16,71 \%$ pada tahun 2012 [3]. Hanya sekitar $12,3 \%$ masyarakat yang menggunakan jasa PDAM [5], sedangkan sisanya menggunakan sumber air yang tak terlindungi seperti air sumur yang memiliki peluang tercemar virus dan bakteri yang dapat menyebabkan beberapa penyakit seperti diare, kolera, tifus, infeksi E- coli, hepatitis A, dan polio.

Penyediaan air bersih yang aman dan layak dikonsumsi dipengaruhi oleh kuantitas dan kualitas sumber air. Kuantitas sumber daya air di Kabupaten Lombok Tengah saat ini dinilai ketersediannya masih mencukupi kebutuhan dengan adanya 46 sungai, 60 embung dan dua bendungan besar yaitu Waduk Batujai dan Waduk Pengga Berdasarkan hasil pengujian kualitas air Waduk Batujai dan sejumlah sungai yang melintasi kota Praya menunjukkan bahwa kadar $\mathrm{BOD}_{5}, \mathrm{COD}$, nitrit air sungai yang melintasi Kota Praya dan waduk telah melebihi ambang batas untuk bahan baku air minum berdasarkan PP 82 Tahun 2001 tentang pengelolaan kualitas air [6]. Hal ini salah satunya disebabkan karena proses leaching pupuk dan pestisida dari lahan persawahan [7] dan pola hidup masyarakat yang mengalirkan air limbah domestik ke sungai baik langsung maupun tidak langsung [6]. Dibutuhkannya sistem pengolahan air minum yang mampu meningkatkan kualitas air minum meliputi aspek fisik, kimia dan biologi sehingga sumber daya air lokal menjadi aman dan layak dikonsumsi masyarakat. Pengolahan air ini dapat menjamin kebutuhan dasar masyarakat akan air bersih dapat terpenuhi.

Solusi yang akan diterapkan dalam kegiatan ini adalah pembangunan unit pengelolaan air minum dengan menggunakan metode gabungan filtrasi-adsorpsi (saringan pasir lambat, karbon aktif dan membran), dan UV radiasi sehingga air hasil pengolahan dapat aman dan layak dikonsumsi dari segi aspek fisik (bau, warna), kimia ( $\mathrm{Fe}$, nitrit, amonia, $\left.\mathrm{BOD}_{5}, \mathrm{COD}, \mathrm{DO}\right)$ dan biologi (bakteri E-coli). Melalui sosialisasi dan pendekatan persuasif, masyarakat diajak untuk ikut berperan aktif menjaga sumber daya air tersedia sehingga pemenuhan kebutuhan air yang aman dan layak dikonsumsisi dapat terwujud. Pembangunan unit pengoahan air siap minum diharapkan menjadi edukasi bagi masyarakat mengenai perilaku hidup bersih dan sehat serta penggunaan air dengan lebih bijak dan efektif.

\section{METODE KEGIATAN}

Program pengabdian bagi masyarakat ini bekerjasama dengan dua mitra, yaitu kelompok tani "Patuh Angen Desa Jago" dan Perkumpulan Petani Pemakai Air (P3A) Desa Jago. Peran mitra kelompok tani sebagai objek alih teknologi pengelolaan air siap minum sekaligus sebagai pengguna produk kegiatan. Sedangkan P3A merupakan organisasi yang berperan dalam pengembangan dan pengelolaan prasarana sistem irigasi dan sebagai wadah kerjasama kelompok tani pemakai air, dibutuhkan pada kegiatan ini sebagai pengelola lanjutan yang akan mengambil alih kegiatan operasional setelah kegiatan IbM selesai.

Kegiatan pengabdian dilakukan dengan pendekatan melalui upaya pemberian pemahaman dan pengetahuan tentang pengelolaan air siap minum dan pengaruh kualitas air terhadap kualitas hidup. Kegiatan diawali dengan survei terhadap kondisi lingkungan Desa Jago terutama tentang sumber daya air. Selanjutnya dilakukan pembangunan sentra pengelolaan air siap minum pada salah satu lahan milik kelompok tani dengan mengutamakan letak strategisnya (baik dari kedekatan sumber air maupun dengan pemukiman anggota kelompok tani yang lain). Rancangan alat pengelolaan air siap minum menggunakan kombinasi filtrasi adsorpsi oleh saringan pasir lambat (terdiri dari pasir silika, arang aktif, sabut kelapa, kapas, dan kerikil) membrane selulosa, granula karbon, karbon aktif, membrane RO (reverse osmosis), dan penyinaran lampu Ultra Violet untuk air siap minum. Sosialisasi kepada kelompok kelompok tani desa jago dilakukan sebagai sarana alih teknologi tentang pengelolaan air siap minum dan sebagai edukasi bagi masyarakat mengenai perilaku hidup bersih dan sehat serta pemanfaatan air secara bijak dan efektif. Keberlanjutan pengolahan air siap minum akan dikelola secara mandiri oleh masyarakat setempat setelah kegiatan IbM selesai dilaksanakan. Kegiatan ini akan dijalankan oleh operator yang telah dilatih sebelumnya dan dibawah pengawasan perangkat Desa. Biaya perawatan dan tenaga operator dibebankan kepada konsumen/masyarakat dengan tarif yang relatif murah sehingga upaya pemenuhan air minum yang aman dan layak bisa dinikmati masyarakat miskin. 


\section{HASIL DAN PEMBAHASAN}

A. Pembangunan sentra alat pengolahan air

Sentra alat pengolahan air dibangun di halaman rumah salah satu warga Desa Jago yang memiliki akses terhadap saluran irigasi sebagai sumber air. Saluran irigasi memiliki debit air yang cukup besar hampir sepanjang tahun sehingga dimungkinkan menjadi bahan baku air siap minum. Akan tetapi, bahan baku air masih memiliki kualitas air tidak layak minum karena masih mengandung pengotor baik padatan terlarut, tidak terlarut maupun mikroorganisme seperti bakteri, virus dll. Oleh karenanya pada unit pengolahan ini selain digunakan sistem filtrasi bertingkat dan berulang juga dibutuhkan desinfikasi untuk mensterilkan air dari mikroorganisme.

Pada prinsipnya unit pengolahan air terdiri dari beberapa bagian yaitu wadah penampung air, pompa air, sistem filtrasi dan lampu uv. Skema alat ditampilkan pada Gambar 1 berikut

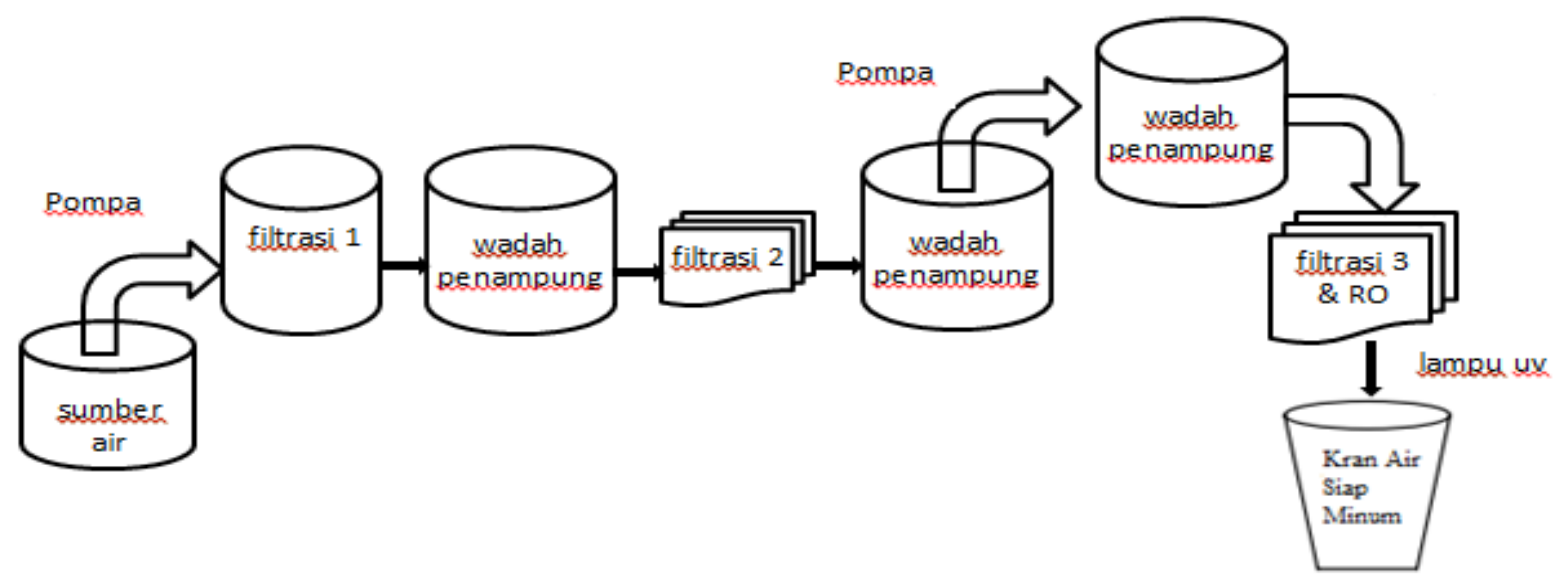

Gambar 1. Skema unit pengolahan air siap minum

Air irigasi ditampung dalam wadah penampung untuk menjamin ketersediaannya sepanjang waktu. Air kemudian dipompa melalui sistem filtrasi 1 yaitu filtrasi saringan pasir lambat. Sistem filtrasi ini dibuat dengan memodifikasi tandon air (secara berturut-turut dari bawah ke atas adalah pasir silika, arang aktif, sabut kelapa, kapas, pasir ukuran kecil, pasir ukuran besar dan kerikil) sehingga dihasilkan sistem penyaringan bertingkat. Filtrasi saringan lambat ini ketika uji coba pertama kali menghasilkan air yang berwarna coklat kemerahan sehingga tidak dapat digunakan langsung. Sistem filtrasi 1 harus dicuci/dibilas selama beberapa hari $( \pm 1$ minggu) untuk menghasilkan air yang jernih.

Prinsip saringan pasir ini memanfaatkan gaya gravitasi sebagai gaya dorong air dan perbedaan ukuran partikel penyusun saringan. Selain proses filtrasi, pada saringan pasir lambat ini juga terjadi proses adsorpsi oleh karbon dari arang dan silika dari pasir sehingga kotoran tertahan di dalam saringan. Pasir halus dengan diameter antara 0,2-0,3 mm berfungsi sebagai saringan telur cacing, kista amoeba, larva cacing sedangkan karbon aktif yang akan mengikat spesies kimia yang tidak diinginkan seperti Fe, $\mathrm{Pb}$, As dan logam lain dalam bentuk senyawa hidroksia atau lainnya melalui proses adsorpsi. Bakteri juga tertahan pada lapisan ini. Air yang keluar dari filtrasi 1 memiliki warna dan bau

yang jauh berkurang dan lebih jernih dibanding bahan baku air pada awalnya.

Laju penyaringan dan tinggi lapisan penyaring berpengaruh terhadap kualitas hasil penyaring. Semakin tinggi lapisan penyaring dan semakin lambat laju alirnya maka penyaringan makin efektif sehingga kualitas hasil penyaring makin baik. Air ditampung pada wadah penampung kemudian masuk pada sistem filtrasi 2 yang memiliki posisi lebih rendah.

Sistem filtrasi 2 terdiri dari membran selulosa, karbon granular dan serbuk karbon aktif. Prinsipnya sama dengan filtrasi 1 yaitu penyaringan sekaligus adsorpsi yang memanfaatkan gaya grafitasi sebagai gaya dorong. Air kemudian masuk ke dalam wadah penampung. Pada tahap ini air kemudian dipompa untuk masuk ke dalam wadah penampung yang posisinya lebih tinggi. Hal ini perlu dilakukan karena dibutuhkan ketinggian tertentu (perbedaan tekanan) untuk dapat mendorong air pada sistem filtrasi 3 dan RO (reverse osmosis). 
Sistem filtrasi 3 sama dengan filtrasi 2 yaitu terdiri dari membran selulosa, karbon granular dan serbuk karbon aktif. Air kemudian masuk ke dalam membran (sistem RO) yang berfungsi untuk menahan kontaminan mikrobiologis bakteri, fungi, protozoa, virus dan ion-ion logam yang dimungkinkan lolos pada proses filtrasi.

Tahapan terakhir adalah desinfikasi air dengan menggunakan lampu ultra violet. Sinar ultraviolet adalah suatu energi yang memiliki kemampuan untuk melakukan penetrasi ke dinding sel mikroorganisme dan mampu mengubah komposisi asam nukleatnya. Absorbsi ultraviolet oleh DNA (atau RNA pada beberapa virus) dapat menyebabkan mikroorganisme tersebut tidak mampu melakukan replikasi akibat pembentukan ikatan rangkap dua pada molekul-molekul pirimidin.
Sinar UV dipiih sebagai metode desinfikasi karena memiliki beberapa keuntungan yaitu sangat efektif dalam membunuh sebagian besar bakteri patogen seperti E. coli, tanpa bahan kimia, tidak beracun, tidak menghasilkan produk sampingan yang beracun (significant nontoxic), tidak berbahaya pada kelebihan dosis, menghilangkan beberapa kontaminan organik, tidak memiliki emisi senyawa organik yang mudah menguap atau emisi udara beracun, tidak terjadi perubahan bau dan tidak berbau pada produk akhir, cukup dengan sedikit waktu kontak (detik atau menit) untuk desinfeksi kimia, dan tidak memerlukan penyimpanan bahan berbahaya. Tahapan pembangunan unit pengolahan ditampilkan pada Gambar 2 berikut

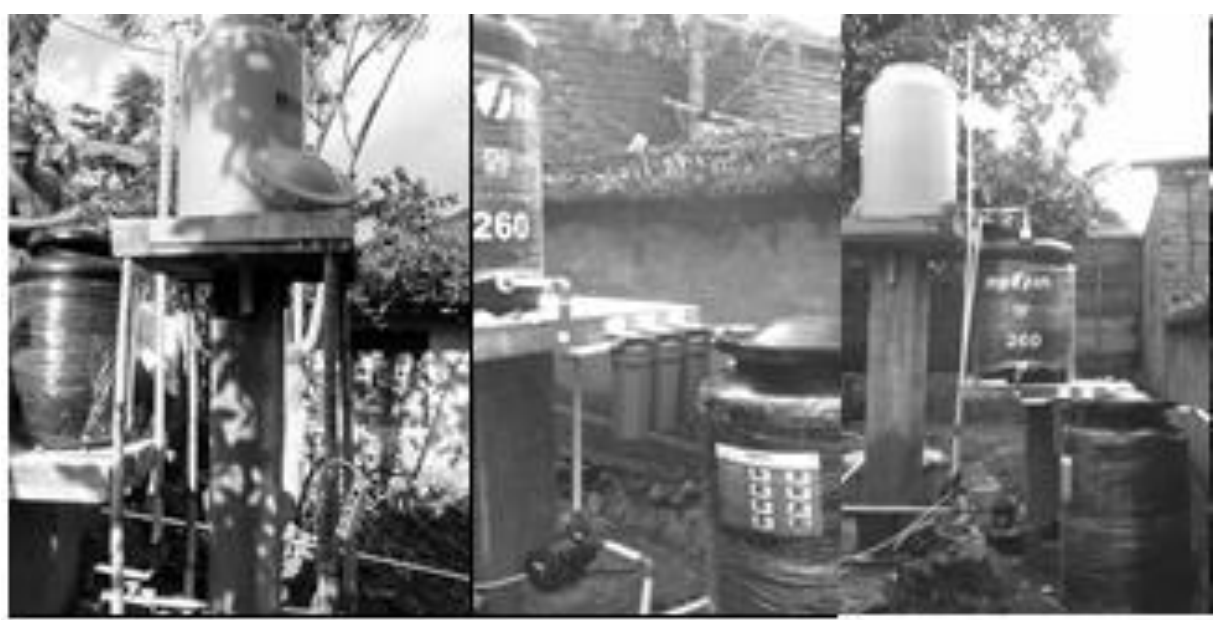

Gambar 2. Pembangunan unit pengolahan air siap minum

\section{B. Sosialisasi Kegiatan}

Kegiatan sosialisasi dilakukan dengan mengundang berbagai elemen masyarakat yaitu Kepala Desa, Kepala Dusus, beberapa perwakilan kelompok-kelompok tani di Desa Jago, anggota P3A dan ibu rumah tangga. Peserta diberian pemahaman dan pengetahuan tentang pentingnya pola hidup sehat dan hubungan air bersih dengn kesehatan dan lingkungan. Selain itu masyarakat diajak untuk ikut berperan aktif menjaga sumber daya air tersedia sehingga pemenuhan kebutuhan air yang aman dan layak dikonsumsisi dapat terwujud.

Pemaparan materi tentang prinsip dasar pengolahan air siap minum menjadi materi inti yang disampaikan pada sosialisasi ini. Metode yang digunakan adalah ceramah dan dilanjutkan dengan diskusi/tanya jawab untuk mengetahui sejauh mana pemahaman peserta dalam menerima materi seperti tampak pada Gambar
3. Kegiatan sosialisasi dilanjutkan dengan pengenalan alat secara langsung dan mencoba minum air hasil pengolahan.

Peserta sangat antusias mengikuti kegiatan ini, diindiasikan dengan banyaknya pertanyaan-pertanyaan yang diajukan terutama mengenai cara mengatasi air yang berbau, produktivitas dan kapasitas alat serta keamanan konsumsi air pengolahan yang dihasilkan. Peserta merespon positif terhadap alih teknologi ini karena dapat memenuhi kebutuhan air minum mereka dengan harga yang terjangkau. Pembangunan sentra pengelolaan air siap minum diharapkan menjadi edukasi bagi masyarakat mengenai perilaku hidup bersih dan sehat serta penggunaan air dengan lebih bijak dan efektif. 


\section{KESIMPULAN}

Telah dibuat alat pengolahan air siap minum dengan menggunakan gabungan teknik filtrasi, adsorpsi, RO dan desinfikasi lampu UV. Respon masyarakat sangat baik dan aktif selama pelaksanaan kegiatan dan berharap produk kegiatan ini merupakan solusi untuk memenuhi kebutuhan air minum yang aman dengan harga terjangkau.

\section{UCAPAN TERIMA KASIH}

Ucapan terimakasih disampaikan kepada pihak DP2M KEMENRISTEK-DIKTI yang telah memberikan dana kegiatan pengabdian kepada masyarakat pada tahun 2017 melalui skim Ipteks bagi Masyarakat (IbM). Ucapan yang sama disampaikan kepada kelompok tani Patuh Angen Desa Jago dan P3A Desa Jago Kab. Lombok Tengah sebagai mitra kegiatan.

\section{DAFTAR PUSTAKA}

[1] Pemerintah Daerah Kabupaten Lombok Tengah Dinas Kesehatan, 2011, Profil Dinas Kesehatan Kabupaten Lombok Tengah 2011, diakses dari www. depkes.go.id pada Tanggal 1 Mei 2016.

[2] Pemerintah Kabupaten Lombok Tengah Badan Perencanaan Pembangunan Daerah,
2012, Buku Putih Sanitasi Kabupaten Lombok Tengah 2012 diakses dari www. Ppsp.nawasis.info pada Tanggal 1 Mei 2016.

[3] Badan Pusat Statistik Provini Nusa Tenggara Barat, 2015, Nusa Tenggara Barat dalam Angka 2015, diakses dari http://ntb.go.id pada Tanggal 25 Mei 2016.

[4] Masduqi, A., N. Endah, E. S. Soedjono, dan W. Hadi. 2007. Capaian Pelayanan Air Bersih Perdesaan Sesuai Millennium Development Goals - Studi Kasus Di Wilayah DAS Brantas, Jurnal Purifikasi, Vol. 8, No. 2, Desember 2007: 115 - 120.

[5] Badan Pusat Statistik Kabupaten Lombok Tengah, 2015, Statistik Daerah Praya 2015, diakses dari http://lomboktengahkab.go.id pada Tanggal 25 Mei 2016.

[6] KPMLH Kabupaten Lombok Tengah, 2003. Data Base Kualitas Lingkungan Hidup Kabupaten Lombok Tengah, Praya.

[7] Myers, B., Williams, E., and Hobgen, S. 2016. Irrigation Water Everywhere - But Is It Fit to Drink?. Prakarsa. Issue 23, January 2016. 